\title{
A 4-year single-center experience in the management of esophageal perforation
}

\author{
Serkan Sarı, M.D., ${ }^{1} \odot$ Hasan Bektaş, M.D., ${ }^{1} \odot$ Kıvılcım Ulusan, M.D.,1 $\odot$ Burak Koçak, M.D., ${ }^{2}$ \\ Bünyamin Gürbulak, M.D., ${ }^{1}$ ○ Şükrü Çolak, M.D., ${ }^{1}$ Ekrem Çakar, M.D., ${ }^{1} \odot$ Melis Baykara Ulusan, M.D. ${ }^{2}$
}

${ }^{1}$ Department of General Surgery, Health Sciences University İstanbul Training and Research Hospital, İstanbul-Turkey
${ }^{2}$ Department of Radiology, Health Sciences University İstanbul Training and Research Hospital, İstanbul-Turkey

\begin{abstract}
BACKGROUND: Esophageal perforation (EP) is a lethal surgical emergency that needs to be diagnosed and treated immediately. Diagnosis and treatment options for EP are limited due to its lower incidence. There are scoring systems proposed for this purpose; however, they cannot be applied to every patient. The recent trend in the treatment of EP is toward the non-operative approach over the surgical treatment methods. The purpose of the present study was to evaluate our treatment methods and outcomes in patients with EP.

METHODS: Thirteen patients with EP treated in our clinic between 2013 and 2017 were retrospectively reviewed. The Pittsburgh Perforation Severity Score (PSS), systemic condition status, and Clavien-Dindo Classification (CDC) score were assessed, and treatment methods were reviewed. Their effects on morbidity and mortality were examined using Fisher's exact test and biserial correlation test.

RESULTS: A total of 13 patients (six males and seven females; median age 64 years) were included in the study. Ten patients were managed non-operative, and three were treated surgically. Of the 10 patients, two had additional surgery after non-operative management. The PSS, systemic condition status, CDC score, duration of stay in the hospital, time to diagnosis, presence of hypotension, and being in shock were strongly correlated with mortality $(p<0.05)$. The PSS, CDC score, and stay in the intensive care unit were strongly correlated with morbidity $(\mathrm{p}<0.05)$. The comparison between the non-operative and operative groups did not yield a statistically significant difference in mortality and morbidity.
\end{abstract}

CONCLUSION: Even if the scoring systems help to understand the severity of the condition, they are inadequate to determine the treatment option. Early diagnosis and treatment are the most important steps in management. Operative and non-operative treatment options are not superior to each other, but their complementary use will be more beneficial for the patients.

Keywords: Esophageal perforation; Pittsburgh Perforation Severity Scoring system; systemic condition scoring system.

\section{INTRODUCTION}

Esophageal perforation (EP) is a rare condition, and the management of this emergency situation is still controversial. Despite advances in technology and surgical techniques, EP continues to be a life-threatening condition. The mortality and morbidity rates were reported up to $40 \%$. $^{[1,2]}$ The most common cause of death in patients with EP is sepsis, which leads to multiorgan failure. ${ }^{[3]}$ The esophagus has no serosal surface; thus, thoracic perforations could cause dissemination of the surrounding tissues and lead to mediastinitis. EP has a wide etiological spectrum and is classified into three groups as spontaneous, traumatic, and iatrogenic perforation. Spontaneous perforation was reported to be more common in previous studies. However, recent studies reported that iatrogenic perforations are up to $60 \%$ of all perforations due to the widespread use of endoscopic procedures. Regardless of its etiology, EP is an emergency. ${ }^{[4,5]} A$ variety of clinical symptoms on presentation and follow-up might delay diagnosis, especially in asymptomatic patients. The mortality rate doubles if EP is not diagnosed in the first $24 \mathrm{~h}$. Thus, early diagnosis is crucial in the treatment. Once EP is diagnosed, hemodynamic

Cite this article as: Sarı S, Bektaş H, Ulusan K, Koçak B, Gürbulak B, Çolak Ş, et al. A 4-year single-center experience in the management of esophageal perforation. Ulus Travma Acil Cerrahi Derg 2019;25:39-45.

Address for correspondence: Kıvılcım Ulusan, M.D.

Sağlık Bilimleri Üniversitesi, İstanbul Eğitim ve Araştırma Hastanesi, Genel Cerrahi Anabilim Dalı, İstanbul, Turkey.

Tel: +90 212 - 4596000 E-mail: kivilcimulusan@hotmail.com

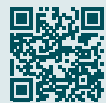

Ulus Travma Acil Cerrahi Derg 2019;25(I):39-45 DOI: 10.5505/tites.2018.79484 Submitted: 16.05.2018 Accepted: 29.08.2018 Online: 28.12.2018

Copyright 2019 Turkish Association of Trauma and Emergency Surgery 
monitoring and support and antibiotic therapy should be initiated. Extraluminal contamination should be controlled, and luminal integrity might be restored in selected cases. There are no widely accepted treatment algorithms and scoring systems that might influence the outcome of patients with EP. ${ }^{[6]}$ Previously, an aggressive surgical approach was advocated. However, recent literature also supports conservative treatment for selected cases. Therefore, a multidisciplinary approach is important in this manner. ${ }^{[7-9]}$

The purpose of the present study was to present a 4-year single-center experience in the management of EP.

\section{MATERIALS AND METHODS}

\section{Study Ethics}

The ethics review board of the University of Health Sciences, Istanbul Training and Research Hospital approved the study (no.: 01.12.2017/II3I).

\section{Study Design}

Patients with EP who were diagnosed and treated at our institution between 2013 and 2017 were retrospectively reviewed. Exclusion criteria were the following: (I) anastomotic leak after upper gastrointestinal (UGI) surgical procedures and (2) esophageal injuries that were diagnosed and treated intraoperatively. Selected patients were diagnosed with chest X-ray, UGI, and thoracic computed tomography (CT) with or without oral contrast and UGI endoscopy. Perforation was classified as etiology (spontaneous, traumatic, and iatrogenic), the location of perforation (cervical, thoracic, and abdominal), perforation size, and presence of additional esophageal pathology or cancer. Time to diagnosis, vital signs, and laboratory parameters at presentation were recorded. Systemic conditions were classified according to the World Health Organization definition criteria as shock, systemic inflammatory response syndrome (SIRS), and non-SIRS.

The Pittsburgh Perforation Severity Scores (PSSs) of all patients were calculated according to the study by Abbas et al. Patients were rated as follows: I point for age $>75$ years, tachycardia (>100 bpm), leukocytosis (>10,000 WBC/mL), and pleural effusion (on chest $\mathrm{X}$-ray, $\mathrm{CT}$, or barium swallow); 2 points for fever $\left(>38.5^{\circ} \mathrm{C}\right.$ ), uncontained leak (on barium swallow or $\mathrm{CT}$ ), respiratory compromise (respiratory rate $>30$, increasing oxygen requirement, or need for mechanical ventilation), and time to diagnosis $>24 \mathrm{~h}$; and three points for presence of cancer and hypotension. With reference to that, patients were divided into three groups as low PSS $(\leq 2)$, intermediate PSS (3-5), and high PSS (>5). The initial treatment was categorized as operative or non-operative management that included conservative observation, endoscopic stenting, and surgical drainage. Re-interventions following non-operative treatment, reoperation or endoscopic stenting after the initial treatment, necessary treatments in the intensive care unit (ICU), duration of stay in the ICU and hospital, mortality, and morbidity were recorded for all patients.

\section{Statistical Analysis}

Statistical data were analyzed using the SPSS version 20 software (SPSS Inc., Chicago, IL, USA). Continuous variables are presented as mean \pm standard deviation and median. Categorical variables are expressed as numbers. The ShapiroWilk test was used for testing the normality of continuous variables. Statistical comparison between the non-operative and surgical groups was made using non-parametric (Fisher's exact test or chi-square test) or parametric tests (independent t-test) considering the distribution pattern of the data. Although at the time of conceptualization of the study, it was planned to use regression analysis for assessing the association of risk factors with management strategies, this did not prove possible because the number of patients in our study was very small $(n=13)$. Hence, simple correlation tests were used for the association of mortality and morbidity with pertinent variables. The correlation tests used were pointbiserial correlation test for dichotomous and continuous variables, rank-biserial correlation test for dichotomous and ordinal variables, and Fischer's exact test for both dichotomous variables. For all statistical tests, a two-tailed $p$-value of $<0.05$ was considered significant.

\section{RESULTS}

Thirteen patients with EP were admitted to our hospital. Ten patients were managed non-operatively. Two out of 10 patients in the conservative treatment group went for surgical intervention in the follow-up. Surgical treatment was the initial approach for three patients. Among 13 patients, three were lost in the non-operative treatment group.

Detailed demographics and their pertinent clinical data are presented in Table I. Comparison of patient demographics and clinical data are presented in Table 2. Comparison between the non-operative and operative groups yielded no statistically significant result.

The PSS and Clavien-Dindo Classification (CDC) score were strongly correlated with morbidity, with high PSS and CDC more associated with morbidity, $r_{p b}=0.61, p=0.026$ and $r_{p b}=0.59, p=0.032$, respectively. Duration of stay in the hospital, PSS score, and CDC score were strongly correlated with mortality, with longer duration of stay and higher PSS and CDC associated with mortality, $r_{p b}=0.56, p=0.043 ; r_{p b}=0.58$, $p=0.034$; and $r_{p b}=0.77, p=0.002$, respectively. Time to diagnosis was strongly correlated with mortality, with the longer time associated with the presence of mortality, $r_{p b}=0.741$, $p=0.004$. Presence of hypotension was associated with the presence of mortality, $p=0.014$. Duration of stay in the ICU was associated with the presence of morbidity, $p=0.014$. Systemic condition status was associated with mortality, with 


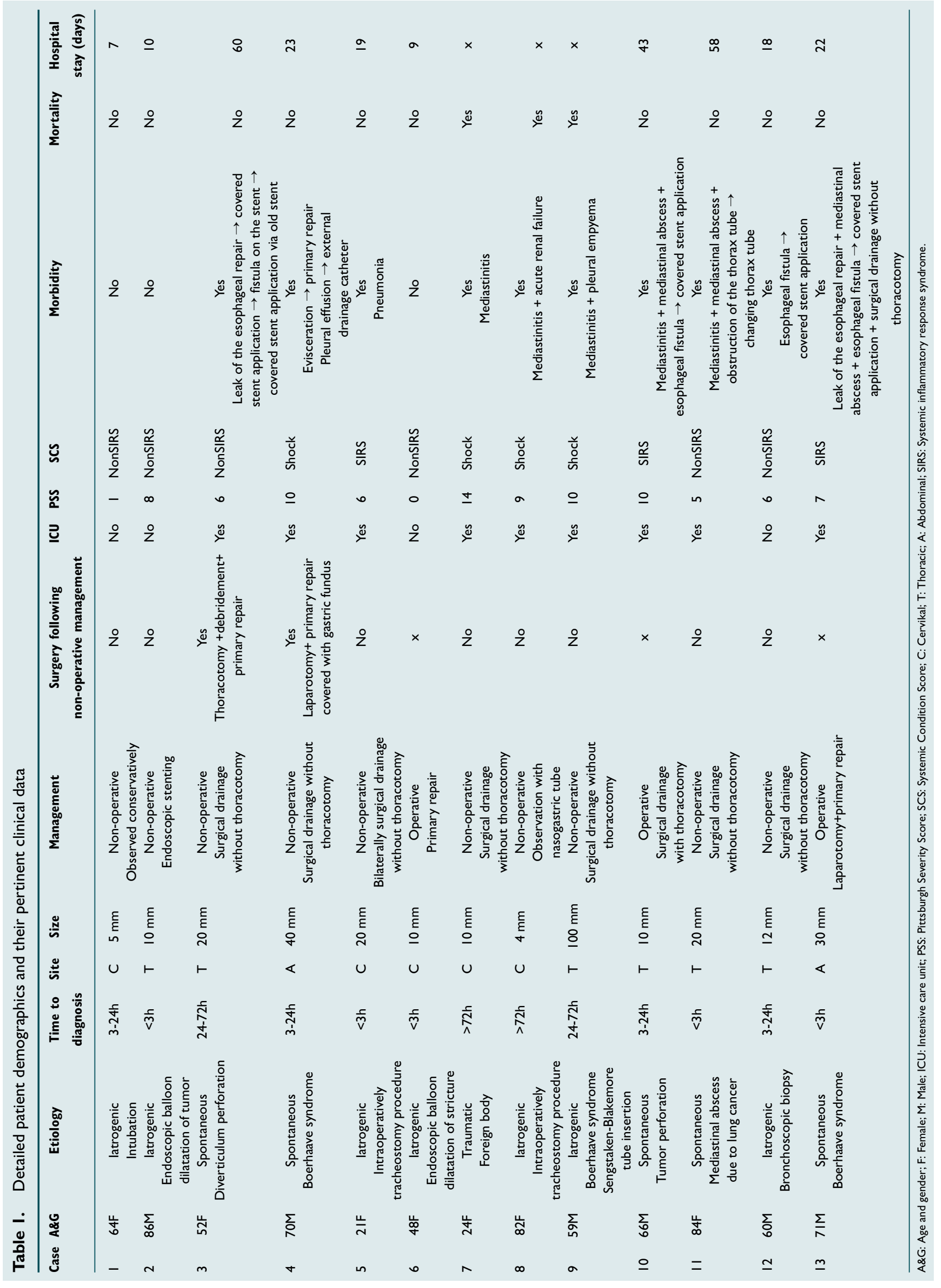


Table 2. Comparison of patient demographics and clinical data

\begin{tabular}{|c|c|c|c|c|}
\hline Groups & $\begin{array}{l}\text { Overall } \\
(n=13)\end{array}$ & $\begin{array}{l}\text { Non-operative } \\
(n=10)\end{array}$ & $\begin{array}{l}\text { Operative } \\
(n=3)\end{array}$ & $\mathbf{p}$ \\
\hline Age (years; mean $\pm S D / m e d i a n)$ & $60.5 \pm 20.4 / 64$ & $60.2 \pm 22.9 / 62$ & $61.6 \pm 12.1 / 66$ & .919 \\
\hline Gender (count; male/female) & $6 / 7$ & $4 / 6$ & $2 / 1$ & .437 \\
\hline Etiology (count; spontaneous/latrogenic/traumatic) & $5 / 7 / 1$ & $3 / 6 / 1$ & $2 / 1 / 0$ & .494 \\
\hline \multicolumn{5}{|l|}{ Perforation site in the esophagus } \\
\hline (count; cervical/thoracic/abdominal) & $5 / 6 / 2$ & $4 / 5 / 1$ & $\mathrm{I} / \mathrm{I} / \mathrm{I}$ & .612 \\
\hline Perforation size (millimeters; mean $\pm \mathrm{SD} /$ median) & $22.3 \pm 25.4 / 12$ & $24.1 \pm 28.6 / 16$ & $16.6 \pm 11.5 / 10$ & .937 \\
\hline \multicolumn{5}{|l|}{ Presence of additional esophageal pathology } \\
\hline (count; present/absent) & $8 / 5$ & $5 / 5$ & $3 / 0$ & .196 \\
\hline Presence of esophageal cancer (count; present/absent) & $2 / 11$ & $1 / 9$ & $1 / 2$ & .423 \\
\hline Time to diagnosis $(\mathrm{h} ;<3 \mathrm{~h} / 3-24 \mathrm{~h} / 24-72 \mathrm{~h} />72 \mathrm{~h})$ & $5 / 4 / 2 / 2$ & $3 / 3 / 2 / 2$ & $2 / 1 / 0 / 0$ & .569 \\
\hline Body temperature (count; $<38.5^{\circ} \mathrm{C} />38.5^{\circ} \mathrm{C}$ ) & $10 / 3$ & $7 / 3$ & $3 / 0$ & .420 \\
\hline Heart beat per minute (count; $<100$ bpm/ $>100$ bpm) & $7 / 6$ & $6 / 4$ & $\mathrm{I} / 2$ & .437 \\
\hline Hypotension (count; present/absent) & $4 / 9$ & $4 / 6$ & $0 / 3$ & .294 \\
\hline Respiratory compromise (count; present/absent) & $7 / 6$ & $5 / 5$ & $2 / 1$ & .563 \\
\hline White blood cells (count; mean \pm SD/median) & $17100 \pm 9200 / 13500$ & $19400 \pm 9090 / 15250$ & $9300 \pm 4464 / 11200$ & .077 \\
\hline Hematocrit (count; mean $\pm S D /$ median) & $33.8 \pm 3.3 / 33200$ & $34.1 \pm 3.4 / 33.4$ & $33.1 \pm 3.6 / 32.1$ & .685 \\
\hline C-reactive protein (count; mean $\pm \mathrm{SD} /$ median) & $45.7+113.2 / 10.9$ & $57.5 \pm 128.1 / 13.2$ & $6.6 \pm 5.2 / 8.7$ & .076 \\
\hline Pleural effusion (count; present/absent) & $9 / 4$ & $7 / 3$ & $2 / 1$ & .706 \\
\hline Uncontained leak (count; present/absent) & $9 / 4$ & $7 / 3$ & $2 / 1$ & .706 \\
\hline \multicolumn{5}{|l|}{ Surgery following non-operative management } \\
\hline (count; present/absent) & $2 / 11$ & $2 / 8$ & $0 / 3$ & .577 \\
\hline \multicolumn{5}{|l|}{ Intervention after the initial management strategy } \\
\hline (count; absent/re-operation/endoscopic stenting) & $8 / 1 / 4$ & $7 / 1 / 2$ & $1 / 0 / 2$ & .296 \\
\hline Stay in the ICU (count; yes/no) & $9 / 4$ & $7 / 3$ & $2 / 1$ & .706 \\
\hline Duration of ICU stay (days; mean \pm SD/median) & $2.4 \pm 2.7 / 2$ & $2.8 \pm 3 / 2$ & $1.3 \pm 1.1 / 2$ & .573 \\
\hline Duration of hospital stay (days; mean $\pm \mathrm{SD} /$ median) & $20.6 \pm 20.7 / 18$ & $19.5 \pm 22.4 / 14$ & $24.6 \pm 17.1 / 22$ & .573 \\
\hline Duration of feeding (days; mean $\pm \mathrm{SD} /$ median) & $12.1 \pm 14.7 / 10$ & $12.7 \pm 16.8 / 8.5$ & $10.3 \pm 4.5 / 10$ & .811 \\
\hline \multicolumn{5}{|l|}{ Pittsburgh Perforation Severity Scoring system } \\
\hline (count; mean $\pm S D / m e d i a n)$ & $7 \pm 3.7 / 7$ & $7.5 \pm 3.5 / 7$ & $5.6 \pm 5.1 / 7$ & .487 \\
\hline Systemic condition in presentation (count; shock/SIRS/non-SIRS) & $4 / 3 / 6$ & $4 / 1 / 5$ & $0 / 2 / 1$ & .103 \\
\hline Clavien-Dindo classification (count; mean $\pm \mathrm{SD} /$ median) & $3.3 \pm 1.2 / 3$ & $3.6 \pm 1.2 / 4$ & $2.3 \pm 0.5 / 2$ & .160 \\
\hline Morbidity (count; present/absent) & $10 / 3$ & $8 / 2$ & $2 / 1$ & .580 \\
\hline Mortality (count; present/absent) & $3 / 10$ & $3 / 7$ & $0 / 3$ & .420 \\
\hline
\end{tabular}

ICU: Intensive care unit; SIRS: Systemic inflammatory response syndrome; SD: Standard deviation.

being in shock (compared with SIRS and non-SIRS) correlated with mortality, $\mathrm{p}=0.012$.

\section{DISCUSSION}

EP is a rare condition seen in 3.1 per $1,000,000$ people per year. ${ }^{[10]}$ The incidence of injury during diagnostic endoscopy ranged from $0.006 \%$ to $2 \%$ and increased up to $7 \%$ when therapeutic esophageal procedures are included. ${ }^{[1-13]}$ The rate of iatrogenic injury is increased with endoscopic examinations, placement of tubes, stent application, submucosal dissection, and endomucosal resection and up to $60 \%$ in the most recent series. ${ }^{[l]}$ Furthermore, there is substantial heterogeneity in the etiologies of perforation including Boerhaave syndrome, tumor perforation, thoracic trauma, swallowing foreign bodies, and acid or caustic substances. ${ }^{[14-16]}$ In our study, the rate of iatrogenic perforation was $53.8 \%$ and spontaneous perforation was $38.5 \%$. Although similar results are obtained in the literature, the iatrogenic perforation rate will be even higher when the injuries that occur during surgery are also included. 


\section{Diagnostic Tools}

The most common presenting symptoms of EP are thoracic pain $(58 \%)$, dyspnea $(30 \%)$, dysphagia $(24 \%)$, vomiting and nausea $(21 \%)$, coughing $(9 \%)$, and hypovolemic shock (II\%). [1] Malignancy is the most frequently identified underlying pathology. CT is the most commonly used diagnostic tool in all perforation etiologies. Thoracic CT is the gold standard for the identification of EP and associated comorbidities.

In addition, some EPs can be diagnosed during endoscopy. ${ }^{[5]}$ If a perforation is noticed during the procedure, the first step is to close the air insufflation and switch to carbon dioxide $\left(\mathrm{CO}_{2}\right) \cdot \mathrm{CO}_{2}$ is rapidly resorbed and has been shown to reduce post-procedural mediastinal emphysema. The second step is to prevent the spread of pathogens by lowering the high intraluminal pressures due to gas insufflation. Even if diagnosed by endoscopic procedures, thoracic $\mathrm{CT}$ should still be performed for the diagnosis of mediastinitis, mediastinal emphysema, and early-stage collections. ${ }^{[17-19]}$ WBC and CRP values may not be helpful in assessing the severity of the disease at an early-stage. Okumura et al. reported that WBC count $\leq 4000 / \mu \mathrm{L}$ indicates a very serious spontaneous perforation. Rather, in our mortal group, all three patients were in shock, and their WBC counts were $22,300 / \mu \mathrm{L}, 34,900 / \mu \mathrm{L}$, and $10,700 / \mu \mathrm{L}$ respectively.

\section{Scoring Systems}

Owing to the low incidence of EP, physicians have limited experience in diagnosis and treatment. The diagnosis could be easily overlooked and delayed. It has high mortality rates ranging from $4 \%$ to $40 \%{ }^{[5,6]}$ In our study, we also found a mortality rate of $23 \%$. Various scoring and classification systems were proposed to reduce the mortality rate. Okumura et al. classified EP into three groups: shock, SIRS, and non-SIRS. Abbas et al. ${ }^{[20]}$ defined the severity scoring system, and Schweigert et al. conducted a multicenter study using this scoring system. When this scoring system was applied to our patients, it was found that a high PS score was more associated with morbidity and mortality, and that the low-risk group had significantly better results in terms of morbidity, mortality, and duration of hospital stay. When the parameters forming the PS score were assessed separately, only time to diagnosis and hypotension were strongly associated with mortality.

Although these scoring systems alert us to the severity of the illness, it is inadequate to explain most clinical cases. One of the most important problems in our study was that many patients are collected in the same group. In our study, 10 (76.9\%) patients were in the high PS score group. When a treatment algorithm is created using this score, the treatment is not selective. The same treatment applied to many patients does not yield sufficient results. On the other hand, when we classify patients according to the systemic condition scoring system, it appears that the groups are more homogeneous. Owing to this result, we think that the systemic condition scoring system of Okumura et al. may be more effective to define a treatment algorithm. Their scoring system reflects the situation of the patients better, whereas we think that the PS score requires new subgroups or different scoring parameters.

Schweigert et al. recommend that the perforation site should be included in the score because cervical perforation is associated with significantly lower mortality than thoracic or abdominal rupture. On the contrary, in our study, two out of three patients who died had cervical EPs.

\section{Treatment Options}

The treatment management of EP was evaluated into two main groups: surgical and non-surgical. Non-surgical management includes (I) observation with or without nasogastric tube placement, (2) nil per os status, (3) parenteral nutrition, (4) antibiotherapy, and (5) non-surgical drainage procedures. [5] Non-operative techniques have become more popular recently because of the widespread use of endoscopic procedures, such as temporary stenting and clip application. ${ }^{[21-24]}$ In addition, endoscopic vacuum-assisted closure has been reported as a new minimal invasive solution for mediastinal collection and mediastinal abscess that necessitates surgical treatment. ${ }^{[25]}$

Surgical management generally includes primary surgical repair, surgical drainage, and esophageal resection procedures. Direct closure with sutures is recommended only in patients with fresh perforations. Direct closure of the perforation site with single sutures following limited debridement is the therapeutic routine based on an infection or delayed treatment. Primary resection is indicated only in patients with larger esophageal destruction and the last possible option in ultima ratio because of its higher mortality and morbidity rates in the presence of mediastinitis. ${ }^{[26-30]}$ Some surgeons have adopted an additional reinforcement, such as pericardial and pleural flabplasties and fundoplication in patients who undergo surgical revision of a prior endoscopic or surgical treatment. ${ }^{[3]]}$ In our study, we had two patients who underwent surgery following non-operative management. The first patient was treated with debridement and primary repair that leaked from the repair site lately. The patient was brought back to the operating room and a covered stent was applied. The second patient was treated with debridement and primary repair and covered with gastric fundus that healed without any problem. According to our experience, additional reinforcement of the repair site following repair should be considered for revision cases.

Considering the results above, EP treatment is still controversial. Recent data in the literature support both surgical and non-surgical treatment methods. Moreover, a recent study showed that endoscopic interventions can be successful even in patients with sepsis with mediastinitis. ${ }^{[3]}$ The treatment 
method might be chosen based on etiology, size or location of perforation, complications related to the mediastinum, or systemic condition of each patient. ${ }^{[3,6,11,24]}$ However, surgical and non-surgical strategies have no superiority to each other, as seen both in the literature and our study. We think that the variable outcomes in the literature depend on patient selection. The results of the patients with a good systemic status are better.

The main group, which is controversial in EP treatment, is septic, low systemic condition, high-risk patients. Schweigert et al. reported that $40 \%$ of the patients in the non-operative group subsequently require surgical intervention. This rate is $20 \%$ in our series. Yet, when mortal patients are excluded from the study, this rate increases to $28.5 \%$. Furthermore, $40 \%(4 / 10)$ of our surviving patients underwent esophageal stenting due to esophageal fistula and leak of esophageal repair during follow-up.

In conclusion, EP is a life-threatening emergency condition. Early diagnosis and treatment are the most important steps in its management. Although the scoring systems may help us determine the severity of the disease, they may not be adequate for choosing the treatment alternatives. However, the groups can be divided more homogeneously using the systemic condition scoring system. Thus, a more effective treatment algorithm could be generated. Treatment methods are not absolute choices, but should be complementary to each other. A close, careful follow-up is more important than the management preference.

\section{Funding}

The authors received no financial support for the research, authorship, and/or publication of this article.

\section{Conflict of interest: None declared.}

\section{REFERENCES}

1. Zimmermann M, Hoffmann M, Jungbluth T, Bruch HP, Keck T, Schloericke E. Predictors of Morbidity and Mortality in Esophageal Perforation: Retrospective Study of 80 Patients. Scand J Surg 2017;106:126-32.

2. Saxena P, Khashab MA. Endoscopic Management of Esophageal Perforations: Who, When, and How? Curr Treat Options Gastroenterol 2017;15:35-45. [CrossRef]

3. Okumura H, Uchikado Y, Kita Y, Omoto I, Hayashi N, Matsumoto M, et al. Clinical analysis of the diagnosis and treatment of esophageal perforation. Esophagus 2016;13:146-50. [CrossRef]

4. Garas G, Zarogoulidis P, Efthymiou A, Athanasiou T, Tsakiridis K, Mpaka S, et al. Spontaneous esophageal rupture as the underlying cause of pneumothorax: early recognition is crucial. J Thorac Dis 2014;6:1655-8.

5. Sudarshan M, Elharram M, Spicer J, Mulder D, Ferri LE. Management of esophageal perforation in the endoscopic era: Is operative repair still relevant? Surgery 2016;160:1104-10. [CrossRef]

6. Schweigert M, Sousa HS, Solymosi N, Yankulov A, Fernández MJ, Beattie R, et al. Spotlight on esophageal perforation: A multinational study using the Pittsburgh esophageal perforation severity scoring system. J Thorac Cardiovasc Surg 2016;151:1002-9.

7. Schwartz ML, McQuarrie DG. Surgical management of esophageal perforation. Surg Gynecol Obstet 1980;151:668-70.

8. Sepesi B, Raymond DP, Peters JH. Esophageal perforation: surgical, endoscopic and medical management strategies. Curr Opin Gastroenterol 2010;26:379-83. [CrossRef]

9. de Aquino JLB, de Camargo JGT, Cecchino GN, Pereira DAR, Bento CA, Leandro-Merhi VA. Evaluation of urgent esophagectomy in esophageal perforation. Arq Bras Cir Dig 2014;27:247-50. [CrossRef]

10. Vidarsdottir H, Blondal S, Alfredsson H, Geirsson A, Gudbjartsson T. Oesophageal Perforations in Iceland: a Whole Population Study on Incidence, Aetiology and Surgical Outcome. Thorac Cardiovasc Surg 2010;58:476-80. [CrossRef]

11. Fernandez FF, Richter A, Freudenberg S, Wendl K, Manegold BC. Treatment of endoscopic esophageal perforation. Surg Endosc 1999;13:9626. [CrossRef]

12. Antoniou D, Soutis M, Christopoulos-Geroulanos G. Anastomotic Strictures Following Esophageal Atresia Repair: A 20-year Experience With Endoscopic Balloon Dilatation. J Pediatr Gastroenterol Nutr 2010;51:464-7. [CrossRef]

13. Eisen GM, Baron TH, Dominitz JA, Faigel DO, Goldstein JL, Johanson JF, et al; American Society for Gastrointestinal Endoscopy.. Complications of upper GI endoscopy. Gastrointest Endosc 2002;55:784-93.

14. Tamatey MN, Sereboe LA, Tettey MM, Entsua-Mensah K, Gyan B. Boerhaave's syndrome: diagnosis and successful primary repair one month after the oesophageal perforation. Ghana Med J 2013;47:53-5.

15. Aronberg RM, Punekar SR, Adam SI, Judson BL, Mehra S, Yarbrough WG. Esophageal perforation caused by edible foreign bodies: A systematic review of the literature. Laryngoscope 2015;125:371-8. [CrossRef]

16. Mamede RC, de Mello Filho FV. Ingestion of caustic substances and its complications. Sao Paulo Med J 2001;119:10-5. [CrossRef]

17. Maeda Y, Hirasawa D, Fujita N, Obana T, Sugawara T, Ohira T, et al. A pilot study to assess mediastinal emphysema after esophageal endoscopic submucosal dissection with carbon dioxide insufflation. Endoscopy 2012;44:565-71. [CrossRef]

18. Yeh DD, Hwabejire JO, de Moya M, King DR, Fagenholz P, Kaafarani $\mathrm{HM}$, et al. Preoperative evaluation of penetrating esophageal trauma in the current era: An analysis of the National Trauma Data Bank. J Emerg Trauma Shock 2015;8:30-3. [CrossRef]

19. Pasricha PJ, Fleischer DE, Kalloo AN. Endoscopic perforations of the upper digestive tract: a review of their pathogenesis, prevention, and management. Gastroenterology 1994;106:787-802. [CrossRef]

20. Abbas G, Schuchert MJ, Pettiford BL, Pennathur A, Landreneau J, Landreneau J, et al. Contemporaneous management of esophageal perforation. Surgery 2009;146:749-56. [CrossRef]

21. Cameron JL, Kieffer RF, Hendrix TR, Mehigan DG, Baker RR. Selective nonoperative management of contained intrathoracic esophageal disruptions. Ann Thorac Surg 1979;27:404-8. [CrossRef]

22. van Heel NC, Haringsma J, Spaander MC, Bruno MJ, Kuipers EJ. ShortTerm Esophageal Stenting in the Management of Benign Perforations. Am J Gastroenterol 2010;105:1515-20. [CrossRef]

23. Persson S, Elbe P, Rouvelas I, Lindblad M, Kumagai K, Lundell L, et al. Predictors for failure of stent treatment for benign esophageal perforations - a single center 10-year experience. World J Gastroenterol 2014;20:10613-9. [CrossRef]

24. Wu JT, Mattox KL, Wall MJ Jr. Esophageal Perforations: New Perspectives and Treatment Paradigms. J Trauma Inj Infect Crit Care 2007;63:1173-84. [CrossRef] 
25. Smallwood NR, Fleshman JW, Leeds SG, Burdick JS. The use of endoluminal vacuum (E-Vac) therapy in the management of upper gastrointestinal leaks and perforations. Surg Endosc 2016;30:2473-80. [CrossRef]

26. Lawrence DR, Moxon RE, Fountain SW, Ohri SK, Townsend ER. Iatrogenic oesophageal perforations: a clinical review. Ann R Coll Surg Engl $1998 ; 80: 115-8$.

27. Schmidt SC, Strauch S, Rösch T, Veltzke-Schlieker W, Jonas S, Pratschke J, et al. Management of esophageal perforations. Surg Endosc 2010;24:2809-13. [CrossRef]

28. Brinster CJ, Singhal S, Lee L, Marshall MB, Kaiser LR, Kucharczuk
JC. Evolving options in the management of esophageal perforation. Ann Thorac Surg 2004;77:1475-83. [CrossRef]

29. Keeling WB, Miller DL, Lam GT, Kilgo P, Miller JI, Mansour KA, et al. Low Mortality After Treatment for Esophageal Perforation: A SingleCenter Experience. Ann Thorac Surg 2010;90:1669-73. [CrossRef]

30. Bhatia P, Fortin D, Inculet RI, Malthaner RA. Current Concepts in the Management of Esophageal Perforations: A Twenty-Seven Year Canadian Experience. Ann Thorac Surg 2011;92:209-15. [CrossRef]

31. Flynn AE, Verrier ED, Way LW, Thomas AN, Pellegrini CA. Esophageal Perforation. Arch Surg 1989;124:1211-5. [CrossRef]

\section{ORIJINAL ÇALIŞMA - ÖZET}

\section{Özofagus perforasyonları yönetiminde tek merkez 4 yıllık deneyimimiz}

Dr. Serkan Sarı, ${ }^{1}$ Dr. Hasan Bektaş, ${ }^{1}$ Dr. Kıvılcım Ulusan, ${ }^{1}$ Dr. Burak Koçak, ${ }^{2}$ Dr. Bünyamin Gürbulak, ${ }^{1}$ Dr. Şükrü Çolak, ${ }^{1}$ Dr. Ekrem Çakar, ${ }^{1}$ Dr. Melis Baykara Ulusan ${ }^{2}$

${ }^{1}$ Sağlık Bilimleri Üniversitesi, İstanbul Eğitim ve Araştırma Hastanesi, Genel Cerrahi Anabilim Dalı, İstanbul ${ }^{2}$ Sağıık Bilimleri Üniversitesi, İstanbul Eğitim ve Araştırma Hastanesi, Radyoloji Anabilim Dalı, İstanbul

AMAÇ: Özofagus perforasyonu (ÖP), hızlı tanı ve tedavi gerektiren, yaşamı tehdit eden acil cerrahi bir durumdur. Nadir görülmesi tanı ve tedavi seçeneklerini sınılamaktadır. Bu amaçla bazı skorlama sistemleri önerilse de tüm hastalarda uygulanamamaktadır. Son yıllarda ÖP tedavisinde nonoperatif seçenekler operatif yöntemlere göre daha ön plana çıkmaktadır. Bu çalışmanın amacı ÖP olan hastalarına uygulanan tedavi yöntemlerini ve bunların sonuçlarını değerlendirmektir.

GEREÇ VE YÖNTEM: Kliniğimizde 2013 ve 2017 yılları arasında ÖP nedeniyle tedavi gören 13 hasta geriye dönük olarak değerlendirildi. Pitsburg şiddet skorlaması (PŞS), Sistemik kondisyon sınıflaması (SKS), Clavien-Dindo sınıflaması (KDS) tanımlandı ve tedavi yöntemleri incelendi. Bu parametrelerin morbidite ve mortaliteyle olan ilişkileri Fisher tam olasılık testi ve çift serili korelasyon testi ile değerlendirildi.

BULGULAR: Çalışmaya toplamda 13 hasta (6 erkek, 7 kadın; ortanca yaş 64 yıl) dahil edildi. On hastada non-operatif tedavi seçenekleri uygulanırken, üç hastaya cerrahi prosedürler uygulandı. Non-operatif tedavi seçenekleri uygulanan 10 hastadan ikisine sonrasında ek cerrahi prosedür uygulandı. Pitsburg şiddet skorlaması, SKS, KDS skoru, hastanede kalış süresi, tanıya kadar geçen süre, hipotansiyon varlığı ve şok mortalite ile koreleydi $(p<0.05)$. Pitsburg şiddet skorlaması, KDS skoru ve yoğun bakım ünitesinde kalım morbidite ile güçlü korelasyon göstermekteydi $(p<0.05)$. Non-operatif ve operatif grup arasında mortalite ve morbidite açısından anlamlı fark izlenmedi.

TARTIŞMA: Skorlama sistemleri hastalı̆ı̆ şiddetini belirlemede yardımcı olsa da tedavi seçeneklerini belirlemede yetersiz kalmaktadır. Erken tanı ve tedavi hastalı̆̆ı yönetiminde en önemli unsurdur. Operatif ve non-operatif prosedürlerin birbirine üstünlüğü yoktur. Fakat bu yöntemleri birbirlerinin tamamlayııısı olarak kullanmak hastalar açısından daha faydalı olacaktır.

Anahtar sözcükler: Özofagus Perforasyonu; Pittsburgh şiddet skorlama sistemi; Sistemik kondisyon skorlama sistemi.

Ulus Travma Acil Cerrahi Derg 2019;25(I):39-45 doi: 10.5505/tjtes.2018.79484 